NBER WORKING PAPER SERIES

\title{
THE COSTS OF HIRING AND SEPARATIONS
}

John M. Abowd

Francis Kramarz

Working Paper 6110

\author{
NATIONAL BUREAU OF ECONOMIC RESEARCH \\ 1050 Massachusetts Avenue \\ Cambridge, MA 02138 \\ July 1997
}

We would like to thank George Jakubson, Guy Laroque and Philippe Tréhorel for helpful comments and suggestions. We are solely responsible for remaining errors. Abowd acknowledges the financial support of the National Science Foundation (grants SBR 91-11186 and SBR 93-21053) to Cornell University and the National Bureau of Economic Research. The data used in this study are confidential but the authors' access is not exclusive. Other researchers interested in using these data should contact CREST, INSEE, 15 bd Gabriel Péri, 92245 Malakoff Cedex, France. This paper is part of NBER's research program in Labor Studies. Any opinions expressed are those of the authors and not those of the National Bureau of Economic Research.

(C) 1997 by John M. Abowd and Francis Kramarz. All rights reserved. Short sections of text, not to exceed two paragraphs, may be quoted without explicit permission provided that full credit, including $(\mathcal{C}$ notice, is given to the source. 
The Costs of Hiring and Separations

John M. Abowd and Francis Kramarz

NBER Working Paper No. 6110

July 1997

Labor Studies

\section{ABSTRACT}

In this article, we estimate the costs of hiring, separation, and retirement of employees for a representative sample of French establishments in 1992. The estimates are computed using data from three sources: the Wage Structure Survey (ESS), the Workforce Movement Questionnaire (DMMO), and the Occupational Structure Survey (ESE). We show that the estimated costs are generally asymmetric (hiring is cheaper than terminations), increasing, and concave functions of the number of entries or exits (either retirements or terminations). There is a fixed component to each of these costs that is related to the structure of the firm's personnel department. Our estimates imply that firms should not adjust gradually to the desired level of employment.

John M. Abowd

Department of Labor Economics

259 Ives Hall

Cornell University

Ithaca, NY 14853-3901

and NBER

john_abowd@cornell.edu
Francis Kramarz

INSEE/CREST

Département de la recherche

15, bd Gabriel Péri

92245 Malakoff Cedex

FRANCE

kramarz@ensae.fr 


\section{Introduction}

We begin at the intersection of dynamic labor demand analysis (initiated in Oi (1961)), and the study of cost functions. The firm's economic problem is the following. Facing economic shocks, the firm must decide to hire or to terminate some workers. To compute the optimal decision, say, the number of terminations, the firm must take into account different types of costs and benefits: past hiring costs, past training costs (both of which are sunk), termination costs, total compensation (wages and benefits), and marginal productivity for a given level of investment. Once the firm decides to terminate some of its workers, we observe the termination costs. These costs are analysed in terms of both variable and fixed adjustment costs using a cost function in which the explanatory variables are (1) the number of workers that left the firm (variable part) and (2) the structure of the personnel department (fixed part).

As important as the microeconomic problem of adjustment cost is, in its own right, adjustment costs have played a central role in macroeconomic theory and empirical work for three decades. Asymmetry, shape and heterogeneity in the adjustment cost function create the possiblity of very different dynamic aggregate economic responses. As Hamermesh and Pfann (1996) have rightly stressed "Knowledge of structures of adjustment costs is essential for predicting the possibly long and complex path of responses of factor demand to shocks. Because the sources and sizes of adjustment costs affect demands for inputs, knowledge of them should be an important input into debate over the long-run effects of such policies relating to factor demand as mandated severance pay for workers; ..." (p. 1265). We present the first direct evidence on the fixed costs associated with hiring and separations of various types, the asymmetries in these costs and the shape of the adjustment cost functions. These functions can be directly used by macroeconomists in the kinds of models proposed by Caballero and Engel (1993) and Caballero, Engel and Haltiwanger (1997), which originated in the work of Davis and Haltiwanger (1990, 1992).

In this article, we estimate the costs of hiring, separation, and retirement of employees for a representative sample of French establishments in 1992. These estimates are computed using French data from three matched sources. The first source is the Wage Structure Survey, which provides the firms' measures of the hiring and firing costs. It also provides, for some firms, 
the employment and the number of new hires and separations. For firms where this information is missing, we match our dataset with the Workforce Movement Questionnaire (DMMO) which gives, for every establishment with at least 50 employees, the number of new hires and separations in year 1992. Finally, we use the Occupational Structure Survey to evaluate the number of workers employed in the establishment's personnel department.

We show that the estimated adjustment costs are very asymmetric-hiring, ignoring training costs, is much less costly than terminations. Hiring and retirement costs are increasing and concave functions of the number of persons involved with large fixed components. Termination costs are increasing and linear functions of the number of persons terminated, also with large fixed components. The structure of the personnel department constitutes a major component of the fixed part of each of these adjustment costs even though they were not mentioned in Oi's (1961) seminal paper, one of the few articles to provide estimates using firm data (the Harvester Company) for a variety of hiring and separation costs. Hence, firms should not adjust gradually to the desired level of employment and most adjustment should occur through manipulation of the hiring rate and not the separation rate, a fact that has been documented for France (Abowd, Corbel and Kramarz 1997) and for the United States (Lane, Stevens and Burgess, 1997).

In the next section, we give the salient details of the laws and institutions of the French labor market. Section 3 summarizes our data. In section 4 , we present the theoretical and statistical models that motivate our specifications. The results of the empirical analysis are in section 5. Finally, we conclude and relate our findings to the growing interface between empirical labor economics and the macroeconomics of employment flows and unemployment.

\section{Firing: The French Labor Laws}

Since 1979, French labor law has recognized two types of regular employment contracts: fixed duration contracts (CDD, contrat à durée déterminée), which contain a specified employment start date, end date and remuneration, but have restricted use (see Abowd, Corbel, and Kramarz (1997)), and indefinite duration contracts (CDI, contrat à durée indéterminée), which are the normal form of contract and which limit the employer's right to terminate the employee as described below. Although their use is formally restricted, 
CDDs are the more common method of hiring. For example, in 1992, $80 \%$ of all entries into private for-profit or semi-public establishments were through CDD. On the other hand, at the same point in time more than $90 \%$ of the stock of employees in these same establishments were on CDI. For those hired under CDD approximately one in three is eventually converted to CDI. CDD have limited duration and renewal possibilities (18 to 24 months, including renewal) and impose a known termination cost of six percent of the total value of the employment contract. Termination of a CDI is a more complex process.

Employer-initiated termination of a CDI employee can take two broad forms-firing (licenciement), for economic reasons or for cause, and early or normal retirement (préretraite and retraite), both of which are considered terminations under French Labor Law (30 July 1987). ${ }^{1}$ Firing for cause under French Labor Law can take two forms-firing for "serious reason" (cause sérieuse) or for "very serious misconduct" (faute grave). The latter exempts the employer to pay a severance payment, and we have no information on this type of terminations. For all other types of terminations and for retirements, the employer must observe a mandatory waiting period (préavis) and pay a severance payment (indemnité de licenciement). An employer can mandatorally retire a worker if that person can benefit from a full pension paid by the Social Security System; that is, if the worker has been employed in a covered job for at least 37.5 years and is at least 60 years old or if the worker has been employed less time (the exact amount varies) in a covered job but has reached the age of 65 (65 is the mandatory retirement age in most industry level collective agreements-conventions collectives). Retirement timing is, thus, an employer decision or, at the least, a joint employee-employer decision. The mandatory waiting period for retirement must be at least as long as that for economic terminations and the severance payment must also be at least equal to the severance payment given in case of economic termination.

Terminations for economic reasons can affect both individual workers and groups of workers (licenciement collectif). All terminated workers benefit from a reemployment priority within the same firm for one year after the termination date. Valid economic termination reasons include: destruction of the worker's job, transformation of the worker's job, and major modification (modification substantielle) of the labor contract without a change in

\footnotetext{
${ }^{1}$ This section heavily borrows from Lamy Social (1992).
} 
the job-leading to termination if the worker refuses to sign the new contract. Major modifications of the job occur when, because of bad business conditions or because of technical change within the firm, existing jobs must be re-engineered to fit the new circumstances. Technical transformations of the job do not necessarily entail a decrease in total employment or the wholesale replacement of workers whose skills are obsolete with new workers whose training is better suited to the re-designed job.

Because different rules apply to individual and collective terminations, we discuss both in turn. For individual terminations, the employee must be notified in writing of the termination and its justification. Although the employer need not inform the personnel delegate (elected representative of the employees to the comité d'entreprise), the administrative authority (Direction du Travail) at the Ministry of Labor must be informed. The administrative authority cannot block the termination unless there has been a procedural error. Before the termination, the employee has the right to an exit interview (entretien préalable). If a re-training program (convention de conversion) is offered, the details must be given in the exit interview. This procedure takes at most 3 weeks. Re-training programs may be tailored to individual needs and are arranged jointly by the firm, the semi-governmental agency that administers the unemployment insurance system, and the national government. The firm pays 4,500FF per worker for the re-training program.

There are several types of collective terminations, the first category distinguished by French labor laws is the collective termination of less than 10 workers during a 30 day period. Most steps in this procedure are similar to those described above. The employer must consult the personnel delegate (elected representative to the comité d'entreprise) or the union representatives at the firm. The employer must notify the employee and the Ministry of Labor in writing. Each worker has the right to an exit interview at which the employer may offer a re-training program that is the same as the one described above for individual terminations.

The second category of collective terminations concerns the dismissal of at least 10 workers during a 30 day period. The 2 August 1989 law requires that firms with 50 or more employees formulate a "social plan" before implementing a collective termination of this magnitude or greater. This social plan must place a limit on the total number of terminations and lay out plans to facilitate reemployment of terminated workers. The plan may also offer a re-training program, just as the collective terminations noted above 
did. Union representatives or personnel delegates and the departmental director of the Ministry of Labor must also be informed of the plan. Two public meetings of the works council (comité d'entreprise) must be organized with an interval between the meetings of two to four weeks depending upon the number of terminations proposed. The works council may require the firm to hire a consulting accountant (at the company's expense) to help the council with its analysis. During this period, the departmental director of the Ministry of Labor must be continuously informed of the proceedings, the plan, and the names of the proposed terminated workers. The Ministry is responsible for enforcing the procedure but cannot block the terminations if the correct procedures have been followed. The Minister has one month to confirm the procedural correctness of the collective termination. Besides documenting irregularities, the departmental director may also suggest changes to the social plan. In all other regards the rules governing large-scale collective terminations are the same as those noted above for smaller collective terminations.

For all terminations, regardless of the number of employees involved, the rules governing the mandatory notification period are as follows. The notification period is the delay between the worker's formal letter announcing the termination and the actual end of the CDI. Workers with less than 6 months seniority are not given notice. For workers with 6 months to 2 years seniority, the notice period is 1 month. The notice period is 2 months for workers with more than two years of seniority. For engineers, professionals, and managers (cadre), the notice period is three months. If the notice period is not respected, the worker must be fully compensated for the difference between the minimum notice period and the delay actually experienced in the termination. There are, however, no punitive damages.

Severance payments (indemnité de licenciement) are calculated as follows. Unless the sector collective bargaining agreement (convention collective), the firm-level collective bargaining agreement (accord d'entreprise) or the individual contract specify a more generous formula, the legal minimum severance payment (indemnité légale) must be paid to workers with at least two years of seniority. For every year of seniority at the firm the employer must pay 20 hours if the worker is paid by the hour or $1 / 10$ th of the reference wage if the worker is paid by the month. The reference wage is computed as the average monthly wage over the last three months of service at the firm. Furthermore, for most workers, an additional 1/15 of a second monthly ref- 
erence wage must be added for every year of service beyond 10 . This second reference wage is the maximum of the first reference wage and the average wage over the last twelve months.

When terminated workers would not receive a full-rate retirement pension, early retirement may be an option for the firm in case of the terminations for economic reasons. Early-retired workers must be at least age 55. The candidate worker must agree to the early retirement by signing a convention along with the employer and the French government. The convention requires that in consideration for receiving an early payment of retirement benefits, the worker (préretraite) forfaits the difference between the minimum severance payment as stated in the sector collective bargaining agreement and the legal minimum severance payment. As a part of the early retirement package, the firm must pay a one-time supplement of at least $3 \%$ of the daily wage times the number of days the worker would have been paid under the collective bargaining agreement until retirement. Actual supplement rates, again specified in the early retirement agreement (convention de préretraite) lie between 6 and $8 \%$. The semi-governmental agency that manages the unemployment insurance system (UNEDIC) pays approximately the same supplement to the early-retiree. The early retirement payments end as soon as the worker reaches normal retirement age.

\section{Data Description}

This section describes the three source surveys and our procedure for matching them.

\subsection{The Wage Structure Survey}

The first dataset that we use is based on the most recent wave of the French Wage Structure Survey (Enquête Structure des Salaires, ESS 1992). A representative sample of establishments in manufacturing, construction and most service industries was asked for information on (1) the wage-setting policy of the establishment and (2) wages and characteristics of a representative sample of the individuals employed at this establishment in that year. The Data Appendix gives more details on the sampling procedure and the industries covered by the surveys. In this study, we did not use the individual-level in- 
formation and, thus, we restrict this discussion to the relevant establishmentlevel variables:

- total employment is the average full-time monthly employment during the year 1992;

- total hiring, CDD, is the number of employees hired on fixed duration, short-term contracts;

- total hiring, CDI is the number of employees hired on long-term contracts;

- total retirements is the number of employees retiring or taking early retirement;

- total terminations (economic reasons) is the number of employees terminated for economic reasons during 1992 and reported separately for two groups-engineers, professionals, and managers (cadre) and all other workers;

- total terminations (other reasons) is the number of employees terminated for cause during 1992 and reported separately for two groupsengineers, professionals, and managers (cadre) and all other workers;

- total terminations (all reasons) is the sum of the two categories of terminations defined above;

- retirement costs are the sum of early retirement payments paid directly to employees and regular retirement compensation paid directly to the employees;

- severance payments are legally mandated separation payments discussed above plus any other payment made by the employer at separation;

- hiring costs are reported employer expenses on job advertising, search firm fees, and compensation of applicants as distinct from employees, explicitly excluding training of newly hired employees.

We also use the following training costs: 
- training hours are the total number of hours of training paid by the firm when trainees were directly compensated by the firm, reported separately for engineers, professionals, and managers (cadre) and for all other workers;

- direct training costs are direct training expenditures exclusive of trainee labor costs and inclusive of payroll costs for instructors as well as all other direct material costs, such as the rental of equipment and space;

- trainees' compensation (young) is the direct labor costs (total compensation) for young trainees (stagiaires, apprentis, and others);

- trainees' compensation (others) is all other trainees' direct labor costs (total compensation).

All these costs are reported in 1992 francs. All compensation costs mentioned above are inclusive of employer-paid payroll taxes (cotisation patronale) and employee-paid payroll taxes (cotisation salariale) but exclude employer paid benefits that are not covered by the payroll taxes. We divide the total compensated training time by the number of workers in each of the two skill-groups to get a "per new hire" measure. As a measure of the annual full time wage rate, we define average labor costs per employee as the total wage bill reported in the ESS (inclusive of all payroll taxes and all employee and employer paid benefits) by the total employment. Finally, the last ESS variable we use is a direct characterization, asked of the responding manager at every establishment, of the business conditions in that year: good, normal, or bad.

It is worth noting that most of the specialized cost and administrative information reported in the ESS is known by the firms because of the legal regulations surrounding the employment relation that we discussed in section 2. The French training laws ("loi sur la formation continue") specify that all firms with ten (twenty in some cases) or more employees must spend a proportion of their wage bill for continuing in-service training (see Delame and Kramarz 1997). This proportion has constantly increased from 1 percent at the beginning of the $1980 \mathrm{~s}$ to 1.2 percent at the end of the decade to 1.4 percent in 1992. The flow data on entries and exits must be declared for the DMMO (see below). The hiring and firing costs are regulated by the laws discussed above. Finally, most of these costs are subject to special tax 
treatment and must, therefore, be accounted separately from other direct costs.

\subsection{The Workforce Movement Questionnaire}

Our second data source was the Monthly Worker Movement Report (Déclaration Mensuelle de Mouvement de Main-d'Oeuvre, DMMO), which is an administrative record of all worker movements at all establishments with at least 50 employees. Although this administrative report was created in the 1970s as a part of the government's monitoring of employee terminations, it was first computerized in 1987 for all of France. Each establishment with at least 50 employees must report for each employment movement: (1) the nature of the transaction- (a) hire on a long-term contract (contrat à durée indéterminée, CDI), (b) hire on a short-term contract (contrat à durée déterminée, CDD), (c) trial hire (période d'essai), (d) transfer in (entrée par transfert), (e) transfer out (sortie par transfert), (f) quit (démission), (g) exit for military service (départ au service national), (h) exit for sickness or death, (i) end of shortterm contract (fin de CDD), (j) end of trial hire (fin de période d'essai) (k) retirement and early retirement (retraite et préretraite), (l) termination for economic reasons (licenciement économique), and (m) other terminations including for cause (autre licenciement); (2) the skill level of the job involved (two-digit occupational code, CS); and (3) the age and seniority of the employee involved. For this study, we created a working file in which the data were summed to the annual level by skill group aggregates for each establishment. The variables used in our analysis were:

- total hiring (CDI) is the number of long-term contract hires;

- total hiring (CDD) is the number of short-term contract hires;

- total retirements is the number of regular and early retirements;

- total terminations (economic reasons) is the number of terminations for economic reasons as defined in section 2 .

The DMMO working file contains information for 38,592 establishments (private and semi-public) for 1992. 


\subsection{The Occupational Structure Survey}

Our third data source is the 1992 Occupational Structure Survey (Enquête sur la Structure des Emplois, ESE), which is an annual administrative data base of the detailed occupational structure for all establishments with at least 20 employees. All establishments from the private or market-oriented public sector (établissement public industriel et commercial, EPIC) with at least 20 employees on December 31, 1991 had to complete a questionnaire. The establishment reports a description of its occupational structure using a 4-digit standardized classification of occupations. From this classification, we defined the following variables:

- clerical worker (personnel department) are all clerical workers (secretaries, assistants, etc.) employed in personnel or legal departments;

- supervisors (personnel department) are all administrative technicians (compensation specialists, benefits specialists, bookkeepers, etc.) and supervisors employed in personnel or legal departments;

- professionals, managers (personnel department) are all professionals (lawyers, MBAs) and managers (human resource managers, personnel directors, compensation managers, benefits managers, etc.) employed in personnel or training departments.

These occupational categories constitute all of the directly identifiable employees in an establishment's personnel or human resource management department. The basic ESE file contains the number of workers employed in these three occupations for 99,904 establishments on December 31, 1991.

\subsection{Creation of the Matched Data File}

We matched our three source surveys by establishment. In the matched file, we required the establishment to be in both the Wage Structure Survey (ESS) and in the Occupational Structure Survey (ESE). Some establishments do not appear in the DMMO and are missing all items from this survey. With this constraint, there were 7,905 establishments matched. These establishments constitute our analysis file. In this analysis dataset, many variables have missing values (not all establishments report retired workers, terminated or 
hired employees). We explain here our methods for constructing the analysis variables and for imputing missing data, when required for the statistical analysis.

For those establishments with no data on total employment from the ESS, we used the available information from the DMMO (average of employment on January 1 and employment on December 31). An equivalent procedure was adopted for the following variables: total hires, total separations for economic reasons, and regular or early retirements: if the data were not available in the ESS, then, we used the figures from the DMMO. Furthermore, when total hires, total separations and retirements were available, but their disaggregation by skill - (a) engineers, managers and professionals or (b) all other categories- was missing, we imputed the values by skill-levels by multiplying the aggregate variable by the respective shares in these two skill-levels in the establishment as declared in the DMMO, no missing data. Finally, we used the data on entry by type of contract-short-term (CDD) or longterm (CDI) - only for those establishments with non-missing data. Table 1 shows the number of available observations for each variable. The number of observations used in the different regressions is shown in our results section.

\section{Theoretical and Statistical Models}

Consider the following labor demand problem for a firm which has profit $\pi_{t}$ at date $t$ of the following form:

$$
\pi_{t}=\left(s_{t}+p_{1}\right) e m p_{t}-\frac{p_{2}}{2} e m p_{t}^{2}-w \times e m p_{t}-C_{f}\left(f_{t}\right)-C_{h}\left(h_{t}\right)
$$

where $s_{t}$ is an i.i.d. shock to the firm's revenue function, $p_{1}$ and $p_{2}$ are strictly positive, $e m p_{t}$ is the firm's employment at date $t, w$ is the wage rate, $f_{t}$ is the number of involuntary separations (early retirements, retirements, and terminations), $h_{t}$ is the number of new hires, $C_{f}($.$) is the firing cost function,$ and $C_{h}($.$) is the hiring cost function. We model these functions as follows:$

$$
C_{f}\left(f_{t}\right)=\alpha_{f, 0}+\alpha_{f, 1} f_{t}+\frac{\alpha_{f, 2}}{2} f_{t}^{2}+\alpha_{f, 3} p e m p_{t} \times f_{t}
$$

if $f_{t}$ is positive, and

$$
C_{h}\left(h_{t}\right)=\alpha_{h, 0}+\alpha_{h, 1} h_{t}+\frac{\alpha_{h, 2}}{2} h_{t}^{2}+\alpha_{h, 3} \operatorname{pemp}_{t} \times h_{t}
$$


if $h_{t}$ is positive; where pemp $p_{t}$ denotes the number of workers employed in the personnel department of the establishment, $\alpha_{j, k}$ are the coefficients of the cost function for $j=f, h$ and $k=0, \ldots, 3$. Institutional costs such as severance payments imposed by the collective agreements, for example, are included in the firing costs. Help wanted advertising costs as well as training costs are included in the hiring costs. In both costs, we included the fixed costs, $\alpha_{i, 0} i=h, f$ due to maintaining a personnel department, which are modeled explicitly in our empirical results. Hence, our cost functions are the sum of a fixed part and a variable part with both parts related to the size of the personnel department.

The firm maximizes the present value of the stream of expected profits, $V$, over an infinite horizon. First, we write $h_{t}$ and $f_{t}$ as functions of employment at $t-1$ and $t$.

$$
\begin{aligned}
& h_{t}=\max \left[0, e m p_{t}-\left(e m p_{t-1}-q_{t-1, t}\right)\right] \\
& f_{t}=\max \left[0,\left(e m p_{t-1}-q_{t-1, t}\right)-e m p_{t}\right]
\end{aligned}
$$

where $e m p_{t}$ denotes employment at date $t$, and $q_{t-1, t}$ denotes exogenous quits between $t-1$ and $t$. The program becomes

$$
V\left(e m p_{t-1}, s_{t}\right)=\max _{e m p_{t}}\left[\pi_{t}+\delta E_{t} V\left(e m p_{t}, s_{t+1}\right)\right]
$$

where $\delta$ is the discount factor. One can show (see, for instance, Bentolila and Saint-Paul (1994)) that the optimal rule for $e m p_{t}$ is given by

$$
\begin{gathered}
s_{t}+p_{1}-p_{2} e m p_{t}-w+\alpha_{f, 1}+\alpha_{f, 2}\left(e m p_{t}-\left(e m p_{t-1}-q_{t-1, t}\right)\right) \\
+\alpha_{f, 3} \operatorname{pemp}_{t}+\delta E_{t} V^{\prime}\left(e m p_{t}, s_{t+1}\right)=0
\end{gathered}
$$

when the firm terminates, and by

$$
\begin{gathered}
s_{t}+p_{1}-p_{2} e m p_{t}-w-\alpha_{h, 1}-\alpha_{h, 2}\left(\left(e m p_{t-1}-q_{t-1, t}\right)-e m p_{t}\right) \\
-\alpha_{h, 3} p e m p_{t}+\delta E_{t} V^{\prime}\left(e m p_{t}, s_{t+1}\right)=0
\end{gathered}
$$

when the firm hires, and that the firm does not change its level of employment as long as:

$$
\begin{gathered}
s_{t}+p_{1}-p_{2}\left(e m p_{t-1}-q_{t-1, t}\right)-w+\alpha_{f, 1}+c_{f, 3} p e m p_{t} \\
+\delta E_{t} V^{\prime}\left(e m p_{t-1}-q_{t-1, t}, s_{t+1}\right) \geq 0
\end{gathered}
$$


and

$$
\begin{gathered}
s_{t}+p_{1}-p_{2}\left(e m p_{t-1}-q_{t-1, t}\right)-w-\alpha_{h, 1}-\alpha_{h, 3} p e m p_{t} \\
+\delta E_{t} V^{\prime}\left(\left(e m p_{t-1}-q_{t-1, t}\right), s_{t+1}\right) \leq 0
\end{gathered}
$$

Hence, the firm is inactive as long as the shock, $s_{t}$, is small enough.

Abstracting from the dating in our problem (we use data for only one year), we estimate equation 1 for retirement and early retirement, for terminations for economic reasons, and for total terminations and equation 2 for new hires. To model the decision to incur the cost implied by equations 3 and 4, we estimate a generalized tobit model. In this tobit model, we estimate simultaneously equations 1 and 3 , in case of separation, and equations 2 and 4 , in case of new hires, by maximum-likelihood. To model the decision to incur the cost implied by equations 3 and 4 , we use the following variables: total employment; all training investments - training hours (cadre), training hours (others), direct training costs, trainees' compensation (young), trainees' compensation (others); good business conditions; bad business conditions; average labor costs per employee; and the employment in the personnel department in three skill levels (clerical workers; technicians; professionals and managers). We also estimate equations 1 and 2 using least squares on establishments with strictly positive reported cost and strictly positive reported movements.

\section{Estimation Results}

Table 1 reports the summary statistics for our sample. Our first estimate of the different costs is given in the table. The 1992 retirement costs per retired worker were 134,011 FF. The termination costs reported in the ESS include all severance payments paid for economic reasons and for cause (other than very serious misconduct). However, the number of workers terminated for cause reported in the ESS and the DMMO includes both workers who were terminated for serious reasons (with severance payment) and workers who were terminated for very serious misconduct (without severance payment). Hence, we give two measures of the cost for terminations. ${ }^{2}$ The first is the ratio of the termination costs to the number of workers terminated for

\footnotetext{
${ }^{2}$ However, firing for very serious misconduct is restricted, and the jurisprudence is favorable to the employees.
} 
economic reasons; in 1992, this ratio is equal to $214,828 \mathrm{FF}$. The second is the ratio of termination costs to the total number of terminated workers (either for economic reasons or for cause); in 1992, this ratio is equal to $95,531 \mathrm{FF}$. The first number gives an upper bound on the termination cost whereas the second gives a lower bound since the total number of terminated workers may include terminations for "very serious misconducts," which are exempted from severance payments. The hiring cost per hire were 5,560 FF. This last figure does not include the training costs. These training costs are also shown in this table. Since the ESS does not directly ask for the training costs for new hires our reported results are computed as the ratio of the training costs to total employment. This assumption probably underestimates the training costs for the new hires since the establishment total training costs were divided by total establishment employment rather than by the employees at risk to be trained. We also give estimates of the average number of workers entering, retiring from, and terminated from the establishment in 1992. Two versions of these statistics are computed. The first includes establishments with no entries, retirements, or terminations. The second does not include these establishments and, therefore, gives us the average size of the groups entering or leaving the firm in a given year. In establishments with positive entry, 64.8 workers were hired (70 to $80 \%$ on short-term contracts, see Abowd et al. 1997). In establishments with positive retirements, the average size of the group of retirees is 7.2. Finally, in establishments with positive termination for economic reasons, the average size of the group of workers fired for economic reasons is 20.0 whereas in establishments with positive termination (for economic reasons or for cause) the average size is 15.0 .

Table 2 reports our results for the determinants of the cost of retirement and early retirement. Columns (1) and (3) are estimated using least squares on observations with strictly positive retirements and strictly positive retirement costs. Columns (2) (4) are estimated by maximum likelihood (generalized tobit) using all observations with either positive costs and positive retirements or zero costs and zero retirement. The least squares and tobit estimates are identical, except for the coefficients on total retirements. In the latter, the linear part is much larger and the function is more concave. This difference is consistent with our model. Least squares should be downward biased; only those establishments with low costs, all other things being equal, should be ready to separate from workers. All estimated coefficients, 
expressed in francs per termination or retirement are large and statistically significant. ${ }^{3}$

Retirement costs are concave in the number of retired workers. Figure 1 shows the shape of the cost curve based on column (4) estimates. The marginal cost of retiring $N$ workers is estimated to be $133,121-676 \times N$ (in 1992 francs), all other things equal. Notice that the retirement cost is increasing in the number of clerks and supervisors employed in the personnel department but that this cost is decreasing in the number of professionals and managers employed in this department. As shown in columns (3) and (4) of Table 2, the introduction of interaction terms between the number of retired workers and the number of employees in the personnel department confirms that the decrease in the cost per retiree comes primarily from the very skilled employees in the personnel department.

Inspection of Table 3, which reports results for retirement costs with the retirees differentiated by skill-levels, shows that the termination costs of retirement stem primarily from retiring engineers, professionals, and managers ("cadres") and not from the retirement of other workers. The cost of retiring workers with other skills is shown to be decreasing and convex in Table 3. Therefore, firms should optimally group retirements of their skilled workers (concave adjustment costs) and retire low-skill workers gradually (convex adjustment costs).

Table $4 \mathrm{a}$ and Table $4 \mathrm{~b}$ report the costs of firing workers. We use our two measures of the number of terminated workers-the number of workers terminated for economic reasons (Table 4a) and the number of all terminated workers (Table $4 \mathrm{~b}$ ). The structure of the table is similar to that of Table 2. The results have the same flavor. ${ }^{4}$ Even though the magnitude of the coefficients slightly differ between Table $4 \mathrm{a}$ and Table $4 \mathrm{~b}$, the structure of the results is similar. First, termination costs are an increasing and ap-

\footnotetext{
${ }^{3}$ We do not report the estimates from the probit part of the generalized tobit. Most coefficients in the probit equation are significantly different from zero. Surprisingly, the variable "facing bad business conditions" has no impact on the retirement probability. Training investments-hours of training per cadre, hours of training per other type of worker, young trainees' labor costs-decrease the retirement probability whereas the size of the establishment, total labor costs per worker, the number of clerical workers employed in the personnel department, other direct training costs, and all other trainees' labor costs increase the retirement probability.

${ }^{4}$ This is also true for the probit results. However, the variable "facing bad business conditions" strongly increases the probability of terminations.
} 
proximately linear function of the number of terminated workers with the personel department acting as a fixed cost (at zero termination, see figure 2 ). Thus, once again, the firm should optimally group the terminations. The termination cost is increasing and concave in the number of professionals employed in the personnel department. It is decreasing and convex in the number of other types of workers employed in the same department (Table 4a) even though the relation is weak (Table 4b). Columns (3) and (4) in both tables confirm that the presence of clerks and supervisors in the personnel department tends to lower these costs.

Table 5 shows the impact of the skill-level of the terminated workers. The cost of termination is an increasing and concave function for both cadres (strongly) and other skills (less so). Such results once more demonstrate that firms should optimally group firings into collective procedures.

Table 6 presents estimates of the cost of hiring new workers. The table reports only least squares results because too few establishments reported both zero costs and zero entries to permit the estimation of the generalized tobit. Column (1) shows that the number of new hires has no impact on the cost per hire. In this equation, the hiring costs consist primarily of the fixed part due to the existence of the personnel department. The coefficient on the number of managers and professionals in the personnel department is the largest, however, all estimated coefficients for personnel employees are large. In column (2), we show the results when we interact the number of new hires with the structure of the personnel department. The coefficients show that these structural costs can be decomposed into two parts-the presence of professionals, managers, or supervisors in this department diminish the costs and the presence of clerical workers increase this cost, whereas every new hire increases the part due to managers by 1,701 FF and every new hire decreases the costs due to clerks and supervisors by, respectively, 40FF and 236FF.

Table 7 reports the structure of hiring costs when we differentiate the hires by skill-level. The hiring costs are due primarily to entry of engineers, professionals, and managers. Table 8 shows, on a small subsample, that the type of contract matters. Hiring costs are due entirely to entry of highly-skilled workers on long-term contracts (CDI). Once again, the cost function is increasing and concave; thus, firms should group their hiring of engineers, professionals, or managers. These two tables also confirm our previous findings on the impact of the skill structure of the personnel department-decreasing costs as 
the professional component of the personnel department increases and the opposite for the two other categories of human resource specialists.

\section{Conclusions}

Our results show, for the first time, direct evidence on the shape of firm-level adjustment costs ${ }^{5}$ in contrast to the vast amount of indirect evidence based upon estimating dynamic labor demand equations (see Hamermesh, 1993). In France, at least, adjustment costs are asymmetric (hiring is cheaper than separations) and display two sources of concavity-the fixed costs due to the existence of a personnel department and the concave shape of retirement costs. These results may explain why firms tend to prefer large adjustments over smaller ones, a feature consistent with the microeconomic evidence in the estimates provided by Caballero and Engel (1993) and Caballero, Engel and Haltiwanger (1997). We have presented estimates of the structure of retirement, termination, and hiring costs using, for the first time, representative establishment-level data and directly reported adjustment costs. We have provided estimates of the magnitude of these costs as well as statistical summaries of their functional shape given the number of movements and the structure of the personnel department.

It appears that retirement costs are increasing and concave in the number of retired workers leaving the firm while the termination costs are linear in the number of terminated workers. Furthermore, these costs are never zero, even when no worker leaves or enters the firm because, in particular, the maintenance of a personnel department entails a fixed cost. Hiring costs do not have the same structure for all skill levels. Only hires of cadres on longterm contracts (CDI) have an increasing and concave impact on the cost. For all other skill levels and types of contract, hiring costs do not depend upon the number of entries. Thus, for hiring costs, the firms have an incentive to group the managerial (cadre) hiring but for other hiring the incentives are for smoother activity. The costs of hiring are much less important in France than the costs of separations (retirements and terminations). The structure of the personnel department has a major impact on all types of entry and

\footnotetext{
${ }^{5}$ Pfann and Verspagen (1989) estimated adjustment cost functions using costs of reorganization as reported by employers and net changes in employment, not entries and exits.
} 
exit costs. $^{6}$

Our conclusions must first be related to the market upon which they are based. Wages appear to be rigid in France (see Card, Kramarz, and Lemieux (1996)) so that adjustments occur primarily through employment changes. Indeed, Abowd, Corbel, and Kramarz (1997) have shown the existence of a considerable amount of worker turnover in France, primarily driven by adjustments of hiring. Most of these movements stem from the entry and exit of workers on short-term contracts (CDD). Since the termination or retirement of workers on indefinite duration contracts (CDI) causes adjustment costs in our estimates while the termination of CDD workers does not, the conjunction of rigid wages, high firing costs for workers on CDI, and easy hiring and separation for workers on CDD seems to explain the observed behavior of French firms. In particular, our estimates explain why these firms hire primarily on short term contracts (more than $70 \%$ of all entries in 1990), why they reduce entries in bad times without increasing separations, and why young workers find it difficult to get a job.

All of the microeconomic evidence for France has counterparts in the U.S., which are not very different from those observed in France. The turnover levels are quite similar for the two countries. ${ }^{7}$ The levels of severance payments incurred by the firms tend to be lower in the U.S., in particular for low-wage workers, but the difference is less strong than originally supposed: roughly $40 \%$ of full-time workers employed at medium or large employers are covered by severance payments while only $20 \%$ of those employed at smaller ones (fewer than 100 employees) (see BLS (1993, 1994, 1995)). Survey evidence provides even higher severance pay incidence estimates, respectively $90 \%$ and $66 \%$ (see Lee Hecht Harrison in BNA (1996)). The same private survey reports an average maximum severance of 39 weeks for executives, 32 weeks for exempts, and 30 weeks for non-exempts. In addition, the experience rating in the UI system increases the costs of separations in the U.S. relative to France where there is no such experience rating system. Hence, there are good reasons to believe that our estimates of the adjustment cost functions are applicable beyond France.

\footnotetext{
${ }^{6}$ We remind the reader that our estimates are based on a single cross-section of establishments and, thus, may be due to compositional effects rather than any single firm's cost structure.

${ }^{7}$ See Anderson and Meyer (1994) and Lane, Stevens and Burgess (1997) for the U.S. and Abowd, Corbel and Kramarz (1997) for France.
} 
Like minimum wages, hiring and separation costs induce labor market rigidities and may be associated with complicated aggregate dynamics. However, the link between these labor market rigidities, employment dynamics and the level of unemployment, particularly the high French unemployment rate, is difficult to assess. There is a strong incentive to avoid adjustment costs in France by a particular strategy-the use of CDD contracts, leading to an increase of the flows into and out of unemployment by younger workers; however, as Blanchard and Katz (1997) show, this need not imply that the equilibrium rate of unemployment is higher. We prefer to focus on other macroeconomic implications of our adjustment cost functions, in particular, the incentives to use hiring rather than terminations as adjustment tool, as implied by the asymmetry, and the incentive to bunch terminations, as implied by the fixed component and the concavity. 


\section{References}

[1] Abowd J.M. , Corbel P., and F. Kramarz (1997): "The Entry and Exit of Workers and the Growth of Employment: An Analysis of French Establishments," NBER working paper 5551, revised 1997.

[2] Bentolila S., and G. Saint-Paul (1994): "A Model of Labor Demand with Linear Adjustment Costs," Labour Economics, 1, 303-326.

[3] Blanchard O., and L.F. Katz (1997): "What We Know and Do Not Know About the Natural Rate of Unemployment," Journal of Economic Perspectives, 11, 1, 51-72.

[4] Bureau of Labor Statistics (1993): Employee Benefits in Medium and Large Private Establishments, 1991 (Washington: GPO).

[5] Bureau of Labor Statistics (1994): Employee Benefits in Small Private Establishments, 1992 (Washington: GPO).

[6] Bureau of Labor Statistics (1995): Employee Benefits in Medium and Large Private Establishments, 1993 (Washington: GPO).

[7] Bureau of National Affairs (1996): "Severance Practices," Bulletin of Management, Datagraph, January 11, 1996.

[8] Caballero R.J., and E.M.R.A. Engel (1993): "Microeconomic Adjustment Hazards and Aggregate Dynamics," Quarterly Journal of Economics, 108, 2, 359-383.

[9] Caballero R.J., Engel E.M.R.A., and J. Haltiwanger (1997): "Aggregate Employment Dynamics: Building from Microeconomic Evidence," American Economic Review, 87, 1,115-137.

[10] Card D., Kramarz F., and T. Lemieux (1996): "Changes in the Relative Structure of Employment: A Comparison of the United States, Canada, and France," NBER working paper 5487.

[11] Davis S.J., and J. Haltiwanger (1990): "Gross Job Creation, and Destruction: Microeconomic Evidence and Macroeconomic Implications," NBER Macroeconomics Annual, 5, 123-168. 
[12] Davis S.J., and J. Haltiwanger (1992): "Gross Job Creation, Gross Job Destruction, and Employment Reallocation," Quarterly Journal of Economics, 107, 3, 819-863.

[13] Delame, E. and F. Kramarz (1997): "Entreprises et Formation Continue," Economie et Prévision, forthcoming.

[14] Hamermesh, D. (1995): Labor Demand, Princeton University Press.

[15] Hamermesh, D. and G. Pfann (1996): "Adjustment Costs in Factor Demand," Journal of Economic Perspectives, XXXIV, 1264-1292.

[16] Lamy Social (1992): Droit du Travail, Lamy S.A. éditeur, Paris.

[17] Lane J., Stevens D., and S. Burgess (1997): "Churning Dynamics: An Analysis of Hires and Separations at the Employer Level," The American University working paper.

[18] Oi W.Y. (1961): "Labor as a Quasi-Fixed Factor," Journal of Political Economy, 538-555.

[19] Pfann G., and B. Verspagen (1989): "The Structure of Adjustment Costs for Labour in the Dutch Manufacturing Sector," Economics Letters, 29, $4,365-371$.

[20] Rotbart G. (1991): Enquête sur la Structure des Salaires, InseeMéthodes, Insee. 
Table 1: Summary Statistics

\begin{tabular}{|c|c|c|c|}
\hline Variable & Number of Obs. & Mean & Std \\
\hline Total Employment & 7,905 & 195.8 & 595.6 \\
\hline Total Hiring & 4,255 & 61.8 & 128.9 \\
\hline Total Hiring (excludes zeros) & 4,060 & 64.8 & 131.2 \\
\hline Total Hiring (Eng., Prof., Managers "cadres") & 4,165 & 8.03 & 26.41 \\
\hline Total Hiring (Others) & 4,479 & 40.25 & 103.18 \\
\hline Total Retirements & 3,844 & 3.91 & 12.99 \\
\hline Total Retirements (excludes zeros) & 2,084 & 7.21 & 16.95 \\
\hline Total Retirements (Eng., Prof., Managers) & 3,777 & 0.70 & 3.05 \\
\hline Total Retirements (Others) & 2,749 & 3.86 & 10.92 \\
\hline Total Terminations (All Reasons) & 3,809 & 11.07 & 44.77 \\
\hline Total Terminations (Economic Reasons, excludes zeros) & 1,133 & 19.80 & 66.01 \\
\hline Total Terminations (All, excludes zeros) & 2,845 & 14.96 & 51.27 \\
\hline Total Terminations (All, Eng., Prof., Man.) & 3,668 & 1.90 & 8.36 \\
\hline Total Terminations (All, Others) & 2,215 & 11.11 & 41.28 \\
\hline Clerical Workers (Personnel Dept.) & 7,905 & 0.81 & 6.88 \\
\hline Supervisors (Personnel Dept.) & 7,905 & 0.84 & 5.42 \\
\hline Professionals, Managers (Personnel Dept.) & 7,905 & 0.30 & 3.48 \\
\hline Retirement Costs per Retiree & 1,487 & 134,011 & $1,087,370$ \\
\hline Termination Costs per Termination (Eco. Reasons) & 982 & 214,828 & 587,309 \\
\hline Termination Costs per Termination (All) & 2,027 & 95,531 & 233,029 \\
\hline Hiring Costs per Hire & 1,562 & 5560 & 26,240 \\
\hline Training Hours per Eng., Prof., Man. & 7,353 & 86.2 & 2037.2 \\
\hline Training Hours per Others & 7,341 & 68.0 & 2403.6 \\
\hline Direct Training Cost per Worker & 7,896 & 3025.1 & 64686.7 \\
\hline Trainees' Compensation (Young, per Worker) & 7,896 & 458.4 & 11997.5 \\
\hline Trainees' Compensation (Others, per Worker) & 7,896 & 1459.1 & 29427.5 \\
\hline Good Business Conditions (percent) & 7,905 & 4.2 & \\
\hline Bad Business Conditions (percent) & 7,905 & 31.4 & \\
\hline Average Labor Costs & 7,896 & 171,022 & 676,185 \\
\hline
\end{tabular}

Sources: ESS 1992, ESE 1992, DMMO 1992. 
Table 2: The Cost of Retirement and Early Retirement

\begin{tabular}{|c|c|c|c|c|c|}
\hline Variable & $\begin{array}{l}\text { Mean } \\
\text { (Std) }\end{array}$ & $\begin{array}{l}\text { Coef. } \\
\text { (St.E) } \\
(1) \\
\end{array}$ & $\begin{array}{l}\text { Coef. } \\
\text { (St.E) } \\
(2) \\
\end{array}$ & $\begin{array}{l}\text { Coef. } \\
\text { (St.E) } \\
(3) \\
\end{array}$ & $\begin{array}{l}\text { Coef. } \\
\text { (St.E) } \\
(4) \\
\end{array}$ \\
\hline Retirement Costs & $\begin{array}{c}956040 \\
(5263787)\end{array}$ & dep. & dep. & dep. & dep. \\
\hline Total Retirements & $\begin{array}{c}7.72 \\
(16.0)\end{array}$ & $\begin{array}{c}98047 \\
(15682)\end{array}$ & $\begin{array}{l}133121 \\
(17082)\end{array}$ & $\begin{array}{c}93903 \\
(15569)\end{array}$ & $\begin{array}{l}136412 \\
(17266)\end{array}$ \\
\hline $\begin{array}{l}\text { Total Retirements } \\
\text { (squared) }\end{array}$ & $\begin{array}{c}314.7 \\
(1860.4)\end{array}$ & $\begin{array}{c}-74.3 \\
(135.1)\end{array}$ & $\begin{array}{l}-338.1 \\
(144.5)\end{array}$ & $\begin{array}{l}-358.8 \\
(155.8)\end{array}$ & $\begin{array}{l}-661.0 \\
(164.3)\end{array}$ \\
\hline $\begin{array}{l}\text { Clerical Workers } \\
\text { (personnel dept.) }\end{array}$ & $\begin{array}{c}2.37 \\
(12.29)\end{array}$ & $\begin{array}{l}261484 \\
(24600)\end{array}$ & $\begin{array}{l}264898 \\
(24764)\end{array}$ & $\begin{array}{l}311533 \\
(24914)\end{array}$ & $\begin{array}{l}305005 \\
(25142)\end{array}$ \\
\hline $\begin{array}{l}\text { Clerical Workers } \\
\text { (personnel dept., squared) }\end{array}$ & $\begin{array}{c}156.6 \\
(2478.5)\end{array}$ & $\begin{array}{l}-974.7 \\
(119.1)\end{array}$ & $\begin{array}{l}-989.8 \\
(120.0)\end{array}$ & $\begin{array}{l}-1638.9 \\
(140.3)\end{array}$ & $\begin{array}{l}-1616.2 \\
(141.6)\end{array}$ \\
\hline $\begin{array}{l}\text { Supervisors } \\
\text { (personnel dept.) }\end{array}$ & $\begin{array}{c}2.20 \\
(7.16)\end{array}$ & $\begin{array}{l}157885 \\
(37729)\end{array}$ & $\begin{array}{l}156313 \\
(37844)\end{array}$ & $\begin{array}{c}58732 \\
(41596)\end{array}$ & $\begin{array}{c}64146 \\
(41619)\end{array}$ \\
\hline $\begin{array}{l}\text { Supervisors } \\
\text { (personnel dept., squared) }\end{array}$ & $\begin{array}{c}56.0 \\
(501.0)\end{array}$ & $\begin{array}{l}-2060.3 \\
(535.1)\end{array}$ & $\begin{array}{l}-2018.3 \\
(536.1)\end{array}$ & $\begin{array}{l}-1874.4 \\
(544.0)\end{array}$ & $\begin{array}{l}-1874.4 \\
(543.5)\end{array}$ \\
\hline $\begin{array}{l}\text { Professionals, Managers } \\
\text { (personnel dept.) }\end{array}$ & $\begin{array}{c}0.85 \\
(6.74)\end{array}$ & $\begin{array}{r}-131119 \\
(52928)\end{array}$ & $\begin{array}{l}-115280 \\
(53189)\end{array}$ & $\begin{array}{c}11389 \\
(62744)\end{array}$ & $\begin{array}{c}23438 \\
(62896)\end{array}$ \\
\hline $\begin{array}{l}\text { Professionals, Managers } \\
\text { (personnel dept., squared) }\end{array}$ & $\begin{array}{c}46.1 \\
(1460.3)\end{array}$ & $\begin{array}{c}588.2 \\
(236.0)\end{array}$ & $\begin{array}{c}516.8 \\
(237.2)\end{array}$ & $\begin{array}{c}154.0 \\
(272.5)\end{array}$ & $\begin{array}{c}97.0 \\
(273.2)\end{array}$ \\
\hline $\begin{array}{l}\text { Total Retir. } \times \text { Clerks } \\
\text { (personnel dept.) }\end{array}$ & - & - & - & $\begin{array}{c}753.7 \\
(291.9)\end{array}$ & $\begin{array}{c}821.1 \\
(294.2)\end{array}$ \\
\hline $\begin{array}{l}\text { Total Retir. } \times \text { Super. } \\
\text { (personnel dept.) }\end{array}$ & - & - & - & $\begin{array}{l}3375.3 \\
(915.4)\end{array}$ & $\begin{array}{l}3075.3 \\
(920.1)\end{array}$ \\
\hline $\begin{array}{l}\text { Total Retir. } \times \text { Prof., } \\
\text { Managers (personnel dept.) }\end{array}$ & - & - & - & $\begin{array}{l}-4667.8 \\
(1140.3) \\
\end{array}$ & $\begin{array}{r}-4265.5 \\
(1145.3) \\
\end{array}$ \\
\hline $\begin{array}{l}\text { Number of Obs. } \\
\text { R-Squared } \\
\text { Log-likelihood }\end{array}$ & & $\begin{array}{l}1,487 \\
0.278\end{array}$ & $\begin{array}{c}2,928 \\
- \\
-16215.0 \\
\end{array}$ & $\begin{array}{l}1,487 \\
0.318\end{array}$ & $\begin{array}{c}2,928 \\
- \\
-16172.6 \\
\end{array}$ \\
\hline
\end{tabular}

Source: ESS 1992, ESE 1992, DMMO 1992.

Notes : Models (1) and (3) give least squares estimates; models (2) and (4) are estimated by maximum-likelihood (generalized tobit model). Models (1) and (3) rely on establishments with strictly positive costs and strictly positive retirements. 
Table 3: The Cost of Retirement and Early Retirement by Skill-Levels in 1992

\begin{tabular}{|c|c|c|}
\hline Variable & $\begin{array}{l}\text { Mean } \\
(\mathrm{Std})\end{array}$ & $\begin{array}{c}\text { Coef. } \\
\text { (St.E) }\end{array}$ \\
\hline Retirement Costs & $\begin{array}{c}1069506 \\
(5997983)\end{array}$ & dep. \\
\hline Total Retirements & 1.45 & 684268 \\
\hline Eng., Prof., Manag. & $(4.78)$ & $(109647)$ \\
\hline Total Retirements & 24.9 & -7963.7 \\
\hline Eng., Prof., Manag. (squared) & $(269.3)$ & $(2365.4)$ \\
\hline Total Retirements & 6.91 & -78039 \\
\hline Other Skills & $(12.81)$ & $(26740)$ \\
\hline Total Retirements & 211.8 & 2150.4 \\
\hline Other Skills (squared) & $(976.6)$ & $(358.9)$ \\
\hline Clerical Workers & 2.46 & 363633 \\
\hline (personnel dept.) & $(13.32)$ & $(32851)$ \\
\hline Clerical Workers & 183.2 & -1306.0 \\
\hline (personnel dept., squared) & $(2866)$ & $(171.6))$ \\
\hline Supervisors & 1.87 & 16118 \\
\hline (personnel dept.) & $(5.48)$ & $(79608)$ \\
\hline Supervisors & 33.5 & -6.03 \\
\hline (personnel dept., squared) & $(289.8)$ & $(2528)$ \\
\hline Professionals, Managers & 0.54 & -179424 \\
\hline (personnel dept.) & $(2.66)$ & $(125987)$ \\
\hline Professionals, Managers & 7.35 & -5692.7 \\
\hline (personnel dept., squared) & $(121.7)$ & $(4014.5)$ \\
\hline Number of Obs. & & 1,033 \\
\hline R-Squared & & 0.366 \\
\hline
\end{tabular}

Source: ESS 1992, ESE 1992, DMMO 1992.

Notes : Least squares estimates. These equations use only those establishments with strictly positive costs and strictly positive retirements. 
Table 4a: The Cost of Terminations in 1992 (using terminations for economic reasons)

\begin{tabular}{|c|c|c|c|c|c|}
\hline Variable & $\begin{array}{l}\text { Means } \\
\text { (St.D) }\end{array}$ & $\begin{array}{c}\text { Coef. } \\
\text { (St.E) } \\
(1)\end{array}$ & $\begin{array}{c}\text { Coef. } \\
\text { (St.E) } \\
(2) \\
\end{array}$ & $\begin{array}{c}\text { Coef. } \\
\text { (St.E) } \\
(3) \\
\end{array}$ & $\begin{array}{c}\text { Coef. } \\
\text { (St.E) } \\
(4)\end{array}$ \\
\hline Termination Costs & $\begin{array}{c}1619246 \\
(6150543)\end{array}$ & dep. & dep. & dep. & dep. \\
\hline Terminations (Eco.) & $\begin{array}{c}17.7 \\
(57.0)\end{array}$ & $\begin{array}{c}129247 \\
(5832.8)\end{array}$ & $\begin{array}{c}134819 \\
(6035.7)\end{array}$ & $\begin{array}{c}115592 \\
(4701.3)\end{array}$ & $\begin{array}{c}120227 \\
(4812.1)\end{array}$ \\
\hline $\begin{array}{l}\text { Terminations (Eco.) } \\
\text { (squared) }\end{array}$ & $\begin{array}{c}3565 \\
(52417)\end{array}$ & $\begin{array}{c}-105.5 \\
(8.90)\end{array}$ & $\begin{array}{l}-111.6 \\
(9.08)\end{array}$ & $\begin{array}{c}65.4 \\
(12.27)\end{array}$ & $\begin{array}{c}57.3 \\
(12.4)\end{array}$ \\
\hline $\begin{array}{l}\text { Clerical Workers } \\
\text { (personnel dept.) }\end{array}$ & $\begin{array}{c}1.89 \\
(10.1)\end{array}$ & $\begin{array}{l}-73048 \\
(37005)\end{array}$ & $\begin{array}{l}-67171 \\
(37202)\end{array}$ & $\begin{array}{l}-214895 \\
(35689)\end{array}$ & $\begin{array}{l}-203755 \\
(35879)\end{array}$ \\
\hline $\begin{array}{l}\text { Clerical Workers } \\
\text { (personnel dept., squared) }\end{array}$ & $\begin{array}{c}105.4 \\
(2079)\end{array}$ & $\begin{array}{l}1502.9 \\
(226.3)\end{array}$ & $\begin{array}{l}1477.7 \\
(227.8)\end{array}$ & $\begin{array}{l}2790.4 \\
(405.3)\end{array}$ & $\begin{array}{l}2708.0 \\
(407.5)\end{array}$ \\
\hline $\begin{array}{l}\text { Supervisors } \\
\text { (personnel dept.) }\end{array}$ & $\begin{array}{c}1.62 \\
(5.94)\end{array}$ & $\begin{array}{l}-259662 \\
(65316)\end{array}$ & $\begin{array}{l}-212213 \\
(67177)\end{array}$ & $\begin{array}{l}511561 \\
(68877)\end{array}$ & $\begin{array}{l}574957 \\
(70097)\end{array}$ \\
\hline $\begin{array}{l}\text { Supervisors } \\
\text { (personnel dept., squared) }\end{array}$ & $\begin{array}{c}37.8 \\
(392.9)\end{array}$ & $\begin{array}{c}7292.6 \\
(1718.6)\end{array}$ & $\begin{array}{c}6477.5 \\
(1747.0)\end{array}$ & $\begin{array}{l}-8083.1 \\
(2353.9)\end{array}$ & $\begin{array}{l}-9579.1 \\
(2366.6)\end{array}$ \\
\hline $\begin{array}{l}\text { Professionals, Managers } \\
\text { (personnel dept.) }\end{array}$ & $\begin{array}{c}0.74 \\
(3.19)\end{array}$ & $\begin{array}{l}1070020 \\
(84323)\end{array}$ & $\begin{array}{l}1091487 \\
(84555)\end{array}$ & $\begin{array}{l}393032 \\
(73500)\end{array}$ & $\begin{array}{l}387225 \\
(73585)\end{array}$ \\
\hline $\begin{array}{l}\text { Professionals, Managers } \\
\text { (personnel dept., squared) }\end{array}$ & $\begin{array}{c}10.7 \\
(145.5)\end{array}$ & $\begin{array}{l}-7164.8 \\
(802.6)\end{array}$ & $\begin{array}{l}-7370.6 \\
(806.2)\end{array}$ & $\begin{array}{r}-5261.0 \\
(644.0)\end{array}$ & $\begin{array}{r}-5276.6 \\
(645.7)\end{array}$ \\
\hline $\begin{array}{l}\text { Termin. Eco. } \times \text { Clerks } \\
\text { (personnel dept.) }\end{array}$ & & - & - & $\begin{array}{l}-852.9 \\
(89.7)\end{array}$ & $\begin{array}{l}-831.8 \\
(90.3)\end{array}$ \\
\hline $\begin{array}{l}\text { Termin. Eco. } \times \text { Super. } \\
\text { (personnel dept.) }\end{array}$ & & - & - & $\begin{array}{l}-4422.7 \\
(256.2)\end{array}$ & $\begin{array}{l}-4363.0 \\
(256.8)\end{array}$ \\
\hline $\begin{array}{l}\text { Termin. Eco. × Prof., } \\
\text { Managers (personnel dept.) }\end{array}$ & & - & - & $\begin{array}{l}5465.6 \\
(232.1)\end{array}$ & $\begin{array}{l}5494.2 \\
(232.4) \\
\end{array}$ \\
\hline Number of Obs. & & 982 & 2,316 & 982 & 2,316 \\
\hline R-Squared & & 0.654 & $\begin{array}{c}- \\
-10857 ?\end{array}$ & 0.789 & $\begin{array}{c}- \\
-106107\end{array}$ \\
\hline
\end{tabular}

Source: ESS 1992, ESE 1992, DMMO 1992. Notes : Models (1) and (3) give least squares estimates; models (2) and (4) are estimated by maximum-likelihood (generalized tobit). Models (1) and (3) use only establishments with strictly positive costs and strictly positive terminations for economic reasons. 
Table 4b: The Cost of Terminations in 1992 (using all types of terminations)

\begin{tabular}{|c|c|c|c|c|}
\hline Variable & $\begin{array}{l}\text { Coef. } \\
\text { (St.E) } \\
(1)\end{array}$ & $\begin{array}{l}\text { Coef. } \\
\text { (St.E) } \\
(2)\end{array}$ & $\begin{array}{c}\text { Coef. } \\
\text { (St.E) } \\
(3)\end{array}$ & $\begin{array}{c}\text { Coef. } \\
\text { (St.E) } \\
(4)\end{array}$ \\
\hline Termination Costs & dep. & dep. & dep. & dep. \\
\hline Terminations (All) & $\begin{array}{c}77505 \\
(3515.2)\end{array}$ & $\begin{array}{c}87717 \\
(3559.5)\end{array}$ & $\begin{array}{c}74933 \\
(2857.8)\end{array}$ & $\begin{array}{c}83217 \\
(2939.5)\end{array}$ \\
\hline $\begin{array}{l}\text { Terminations (All) } \\
\text { (squared) }\end{array}$ & $\begin{array}{l}-10.6 \\
(8.9)\end{array}$ & $\begin{array}{l}-23.5 \\
(3.8)\end{array}$ & $\begin{array}{l}34.0 \\
(5.6)\end{array}$ & $\begin{array}{l}26.7 \\
(5.7)\end{array}$ \\
\hline $\begin{array}{l}\text { Clerical Workers } \\
\text { (personnel dept.) }\end{array}$ & $\begin{array}{l}-8006.4 \\
(22321)\end{array}$ & $\begin{array}{l}-5228.4 \\
(21549)\end{array}$ & $\begin{array}{l}-50300 \\
(18021)\end{array}$ & $\begin{array}{l}-39298 \\
(17428)\end{array}$ \\
\hline $\begin{array}{l}\text { Clerical Workers } \\
\text { (personnel dept., squared) }\end{array}$ & $\begin{array}{c}98.21 \\
(105.4)\end{array}$ & $\begin{array}{c}132.7 \\
(102.6)\end{array}$ & $\begin{array}{l}-138.5 \\
(87.0)\end{array}$ & $\begin{array}{l}-164.0 \\
(85.5)\end{array}$ \\
\hline $\begin{array}{l}\text { Supervisors } \\
\text { (personnel dept.) }\end{array}$ & $\begin{array}{c}57381 \\
(32126)\end{array}$ & $\begin{array}{l}101364 \\
(31498)\end{array}$ & $\begin{array}{l}311803 \\
(26094)\end{array}$ & $\begin{array}{l}355943 \\
(25665)\end{array}$ \\
\hline $\begin{array}{l}\text { Supervisors } \\
\text { (personnel dept., squared) }\end{array}$ & $\begin{array}{c}220.0 \\
(482.7)\end{array}$ & $\begin{array}{l}-763.6 \\
(457.8)\end{array}$ & $\begin{array}{c}236.1 \\
(680.2)\end{array}$ & $\begin{array}{l}-600.4 \\
(366.0)\end{array}$ \\
\hline $\begin{array}{l}\text { Professionals, Managers } \\
\text { (personnel dept.) }\end{array}$ & $\begin{array}{l}646551 \\
(62166)\end{array}$ & $\begin{array}{l}441685 \\
(47929)\end{array}$ & $\begin{array}{l}329098 \\
(49572)\end{array}$ & $\begin{array}{c}94966 \\
(38934)\end{array}$ \\
\hline $\begin{array}{l}\text { Professionals, Managers } \\
\text { (personnel dept., squared) }\end{array}$ & $\begin{array}{l}-9412.9 \\
(1388.7)\end{array}$ & $\begin{array}{l}-2478.4 \\
(529.4)\end{array}$ & $\begin{array}{l}-9353.4 \\
(1119.2)\end{array}$ & $\begin{array}{l}-1699.3 \\
(416.1)\end{array}$ \\
\hline $\begin{array}{l}\text { Termin. }(\text { All }) \times \text { Clerks } \\
\text { (personnel dept.) }\end{array}$ & - & - & $\begin{array}{l}-78.2 \\
(25.4)\end{array}$ & $\begin{array}{l}-83.7 \\
(25.4)\end{array}$ \\
\hline $\begin{array}{l}\text { Termin. (All) } \times \text { Super. } \\
\text { (personnel dept.) }\end{array}$ & - & - & $\begin{array}{c}-2916.6 \\
(99.0)\end{array}$ & $\begin{array}{c}-2975.6 \\
(98.9)\end{array}$ \\
\hline $\begin{array}{l}\text { Termin. (All) } \times \text { Prof., } \\
\text { Managers (personnel dept.) }\end{array}$ & - & - & $\begin{array}{l}3297.8 \\
(100.6) \\
\end{array}$ & $\begin{array}{l}3234.6 \\
(100.5) \\
\end{array}$ \\
\hline Number of Obs. & 1,982 & 5,455 & 1,982 & 5,455 \\
\hline $\begin{array}{l}\text { R-Squared } \\
\text { Log-likelihood }\end{array}$ & 0.588 & $\begin{array}{c}- \\
-22062.5\end{array}$ & 0.751 & $\begin{array}{c}- \\
-21741.2\end{array}$ \\
\hline
\end{tabular}

Source: ESS 1992, ESE 1992, DMMO 1992. Notes : Models (1) and (3) give least squares estimates; models (2) and (4) are estimated by maximum-likelihood (generalized tobit). Models (1) and (3) use only establishments with strictly positive costs and strictly positive total terminations. 
Table 5: The Cost of Terminations

\begin{tabular}{lccc}
\multicolumn{4}{c}{ by Skill-Levels in 1992 } \\
\hline & Means & Coef. & Coef. \\
Variable & (St.D) & $($ St.E) & $($ St.E) \\
& & $(1)$ & $(2)$ \\
\hline Termination Costs & 1718062 & dep. & dep. \\
& $(6625088)$ & & \\
Terminations & 2.58 & 190544 & 333151 \\
Eng., Prof., Manag. & $(9.80)$ & $(44350)$ & $(29318)$ \\
Terminations & 102.7 & -773.8 & -963.0 \\
Eng., Prof., Manag. (squared) & $(1499)$ & $(284.6)$ & $(166.9)$ \\
Terminations & 17.1 & 120863 & 53333 \\
Other Skills & $(50.9)$ & $(8731)$ & $(4911)$ \\
Terminations & 2884.7 & -80.1 & 10.5 \\
Other Skills (squared) & $(36992)$ & $(16.7)$ & $(7.7)$ \\
Clerical Workers & 2.20 & -165843 & -126552 \\
(personnel dept.) & $(12.4)$ & $(43892)$ & $(28118)$ \\
Clerical Workers & 159.1 & 1479.6 & 653.5 \\
(personnel dept., squared) & $(2686)$ & $(287.8)$ & $(164.0)$ \\
Supervisors & 1.46 & 103373 & 241471 \\
(personnel dept.) & $(5.22)$ & $(99033)$ & $(60005)$ \\
Supervisors & 29.4 & -2584.2 & 5584.7 \\
(personnel dept., squared) & $(281.3)$ & $(2840.1)$ & $(1749.7)$ \\
Professionals, Managers & 0.54 & 1205911 & 747003 \\
(personnel dept.) & $(2.42)$ & $(128240)$ & $(107769)$ \\
Professionals, Managers & 6.16 & -8726.5 & -6418.5 \\
(personnel dept., squared) & $(110.8)$ & $(1098.0)$ & $(3215.7)$ \\
\hline & & & \\
Number of Obs. & & 671 & 1,179 \\
R-Squared & & 0.707 & 0.662 \\
\hline
\end{tabular}

Source: ESS 1992, ESE 1992, DMMO 1992.

Notes : Model (1) uses terminations for economic reasons. Model (2) uses all types of terminations. Both are least squares estimates. Both equations use only establishments with strictly positive costs and with strictly positive terminations. 
Table 6: The Cost of Hiring

\begin{tabular}{|c|c|c|c|}
\hline Variable & $\begin{array}{l}\text { Mean } \\
\text { (Std) }\end{array}$ & $\begin{array}{c}\text { Coef. } \\
\text { (St.E) } \\
(1)\end{array}$ & $\begin{array}{c}\text { Coef. } \\
\text { (St.E) } \\
(2)\end{array}$ \\
\hline Hiring Costs & $\begin{array}{c}218475 \\
(2065041)\end{array}$ & dep. & dep. \\
\hline Total Hiring & $\begin{array}{c}84.7 \\
(159.9)\end{array}$ & $\begin{array}{c}167.9 \\
(464.6)\end{array}$ & $\begin{array}{l}-313.3 \\
(393.3)\end{array}$ \\
\hline $\begin{array}{l}\text { Total Hiring } \\
\text { (squared) }\end{array}$ & $\begin{array}{c}32725 \\
(182935)\end{array}$ & $\begin{array}{l}-0.278 \\
(0.429)\end{array}$ & $\begin{array}{l}-0.479 \\
(0.390)\end{array}$ \\
\hline $\begin{array}{l}\text { Clerical Workers } \\
\text { (personnel dept.) }\end{array}$ & $\begin{array}{c}2.10 \\
(9.88)\end{array}$ & $\begin{array}{l}34959 \\
(9103)\end{array}$ & $\begin{array}{l}36608 \\
(7911)\end{array}$ \\
\hline $\begin{array}{l}\text { Clerical Workers } \\
\text { (personnel dept., squared) }\end{array}$ & $\begin{array}{c}102.1 \\
(1578)\end{array}$ & $\begin{array}{l}-175.9 \\
(53.8)\end{array}$ & $\begin{array}{l}-80.6 \\
(46.8)\end{array}$ \\
\hline $\begin{array}{l}\text { Supervisors } \\
\text { (personnel dept.) }\end{array}$ & $\begin{array}{c}1.70 \\
(6.61)\end{array}$ & $\begin{array}{r}-95440 \\
(14421)\end{array}$ & $\begin{array}{c}-864.1 \\
(13968)\end{array}$ \\
\hline $\begin{array}{l}\text { Supervisors } \\
\text { (personnel dept., squared) }\end{array}$ & $\begin{array}{c}46.5 \\
(493.1)\end{array}$ & $\begin{array}{c}67.0 \\
(190.6)\end{array}$ & $\begin{array}{l}-419.0 \\
(164.2)\end{array}$ \\
\hline $\begin{array}{l}\text { Professionals, Managers } \\
\text { (personnel dept.) }\end{array}$ & $\begin{array}{c}0.89 \\
(7.19)\end{array}$ & $\begin{array}{l}470801 \\
(16125)\end{array}$ & $\begin{array}{l}-8191.2 \\
(22115)\end{array}$ \\
\hline $\begin{array}{l}\text { Professionals, Managers } \\
\text { (personnel dept., squared) }\end{array}$ & $\begin{array}{c}52.4 \\
(1470)\end{array}$ & $\begin{array}{c}-1668.6 \\
(77.8)\end{array}$ & $\begin{array}{l}-309.1 \\
(81.7)\end{array}$ \\
\hline $\begin{array}{l}\text { Total Hiring } \times \text { Clerks } \\
\text { (personnel dept.) }\end{array}$ & - & - & $\begin{array}{l}-40.34 \\
(8.74)\end{array}$ \\
\hline $\begin{array}{l}\text { Total Hiring } \times \text { Super. } \\
\text { (personnel dept.) }\end{array}$ & - & - & $\begin{array}{l}-235.5 \\
(33.8)\end{array}$ \\
\hline $\begin{array}{l}\text { Total Hiring } \times \text { Prof., } \\
\text { Managers (personnel dept.) }\end{array}$ & - & - & $\begin{array}{l}1700.9 \\
(62.3)\end{array}$ \\
\hline $\begin{array}{l}\text { Number of Obs. } \\
\text { R-Squared }\end{array}$ & & $\begin{array}{l}1,562 \\
0.421\end{array}$ & $\begin{array}{l}1,562 \\
0.612\end{array}$ \\
\hline
\end{tabular}

Source: ESS 1992, ESE 1992, DMMO 1992.

Notes : Least squares estimates. Both models use only establishments with strictly positive costs and strictly positive hires. 
Table 7: The Cost of Hiring by Skill-Levels in 1992

\begin{tabular}{lcc}
\hline Variable & $\begin{array}{c}\text { Mean } \\
\text { (Std) }\end{array}$ & $\begin{array}{c}\text { Coef. } \\
\text { (St.E) }\end{array}$ \\
\hline Hiring Costs & 227171 & dep. \\
& $(2434239)$ & \\
Total Hiring & 8.34 & 11266 \\
Eng., Prof., Manag. & $(23.06)$ & $(1873)$ \\
Total Hiring & 601.0 & -24.98 \\
Eng., Prof., Manag. (squared) & $(6341)$ & $(6.23)$ \\
Total Hiring & 73.76 & 710.2 \\
Other Skills & $(156.60)$ & $(238.6)$ \\
Total Hiring & 29944 & -0.539 \\
Other Skills (squared) & $(184662)$ & $(0.196)$ \\
Clerical Workers & 2.17 & 19407 \\
(personnel dept.) & $(10.89)$ & $(3773)$ \\
Clerical Workers & 123.2 & -88.6 \\
(personnel dept., squared) & $(1856)$ & $(21.0)$ \\
Supervisors & 1.43 & 50805 \\
(personnel dept.) & $(5.15)$ & $(7057)$ \\
Supervisors & 28.6 & -1614.1 \\
(personnel dept., squared) & $(311.2)$ & $(108.4)$ \\
Professionals, Managers & 0.65 & -167613 \\
(personnel dept.) & $(4.37)$ & $(11672)$ \\
Professionals, Managers & 19.5 & 6703.7 \\
(personnel dept., squared) & $(447.8)$ & $(106.4)$ \\
\hline & & \\
Number of Obs. & & 1,108 \\
R-Squared & & 0.950 \\
\hline
\end{tabular}

Source: ESS 1992, ESE 1992, DMMO 1992.

Notes : Least squares estimates. The equations use only establishments with strictly positive costs and with strictly positive hires. 
Table 8: The Cost of Hiring by Skill-Level and Contract Type in 1992

\begin{tabular}{lcc}
\hline & Mean & Coef. \\
Variable & (Std) & (St.E) \\
\hline Hiring Costs & 1438353 & dep. \\
& $(8653507)$ & \\
Total Hiring, CDI, & 15.44 & 34839 \\
Eng., Prof., Manag. & $(21.42)$ & $(6719)$ \\
Total Hiring, CDI, & 691.6 & -228.4 \\
Eng., Prof., Manag. (squared) & $(2677)$ & $(58.8)$ \\
Total Hiring, CDD, & 6.29 & 4430.9 \\
Eng., Prof., Manag. & $(27.56)$ & $(12249)$ \\
Total Hiring, CDD, & 790.0 & -23.6 \\
Eng., Prof., Manag. (squared) & $(6784)$ & $(49.7)$ \\
Total Hiring, CDI, & 29.64 & 5506.2 \\
Other Skills & $(60.84)$ & $(3724.8)$ \\
Total Hiring, CDI, & 4536 & -10.15 \\
Other Skills (squared) & $(23649)$ & $(8.96)$ \\
Total Hiring, CDD, & 127.8 & 716.2 \\
Other Skills & $(238.1)$ & $(885.6)$ \\
Total Hiring, CDD, & 72378 & -1.17 \\
Other Skills (squared) & $(230965)$ & $(0.86)$ \\
Clerical Workers & 5.06 & -5567.6 \\
(personnel dept.) & $(12.16)$ & $(13351)$ \\
Clerical Workers & 171.6 & 111.2 \\
(personnel dept., squared) & $(914.0)$ & $(166.4)$ \\
Supervisors & 3.94 & 50808 \\
(personnel dept.) & $(7.41)$ & $(28363)$ \\
Supervisors & 69.85 & -1601.1 \\
(personnel dept., squared) & $(232.0)$ & $(939.0)$ \\
Professionals, Managers & 3.36 & -108302 \\
(personnel dept.) & $(13.54)$ & $(23770)$ \\
Professionals, Managers & 192.4 & 6350.7 \\
(personnel dept., squared) & $(1563)$ & $(193.0)$ \\
Number of Obs. & & 85 \\
R-Squared & & 0.996 \\
\hline & & \\
& & \\
& &
\end{tabular}

Source: ESS 1992, ESE 1992, DMMO 1992. Notes: Least squares estimates. The models use only those establishments with strictly positive costs, with strictly positive hires, and reported data on hires by types of contract and skill-levels. 


\section{Data Appendix}

The Wage Structure Surveys (Enquête sur la Structure des Salaires, ESS hereafter), conducted jointly by the French National Statistical Institute (INSEE) and the Ministry of Labor, were initiated in 1966 by the European Statistical Office (ESO). However, after the 1966, 1972 and 1978 surveys, the ESS was abandoned by the ESO. INSEE decided to resume this survey given the usefulness and quantity of information collected during each wave. The 1992 ESS collects establishment wage information as well as individual wages (employees sampled within the establishment) for a sample of establishments in the manufacturing, construction, and (some) service industries. The sampling frame has two stages: at the first stage, production units are sampled; at the second stage, individuals employed at these sampled units are sampled. More specifically, the universe to be sampled includes all establishments (manufacturing) or firms (construction and service) with at least ten employees. Agriculture, transportation, telecommunication and the services supplied to households are excluded from the scope of the ESS. Insurance companies, banks, and all other industries where services are supplied to businesses are in the scope of the survey. The universe is derived from the SIRENE system, a unified database recording all existing establishments and firms in France. The sampling rate is stratified according to the industry, region, and the size of the unit. Sampling rates vary from 1 (certainty) for the units above 500 employees to $1 / 48$ for units between 10 and 20 employees.

More detailed technical information on the 1986 version of the ESS is available in Rotbart (1991). The technical report on the 1992 version of the ESS is not yet available. 
Figure 1

Total Cost of Retirements at Means

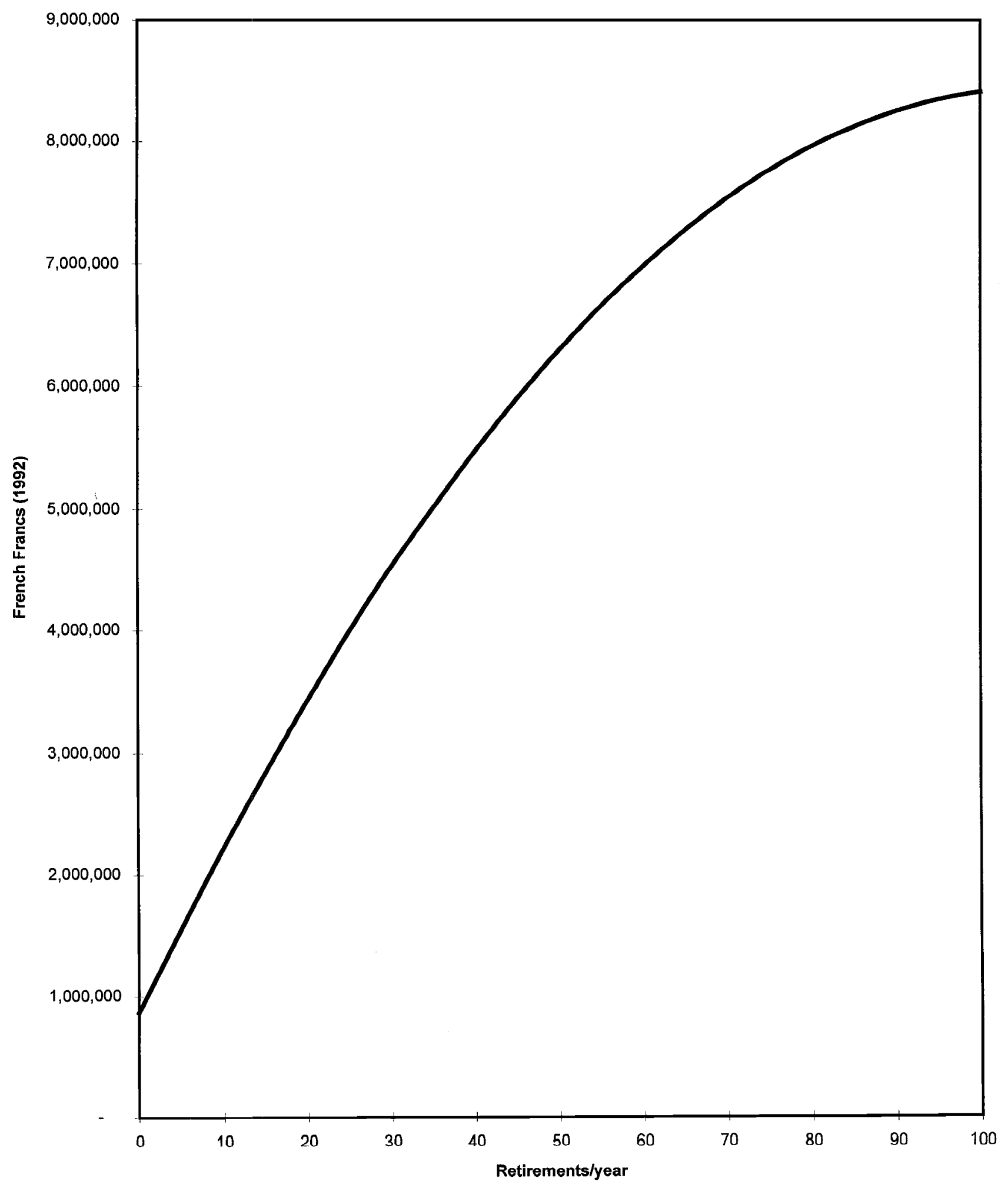


Figure 2

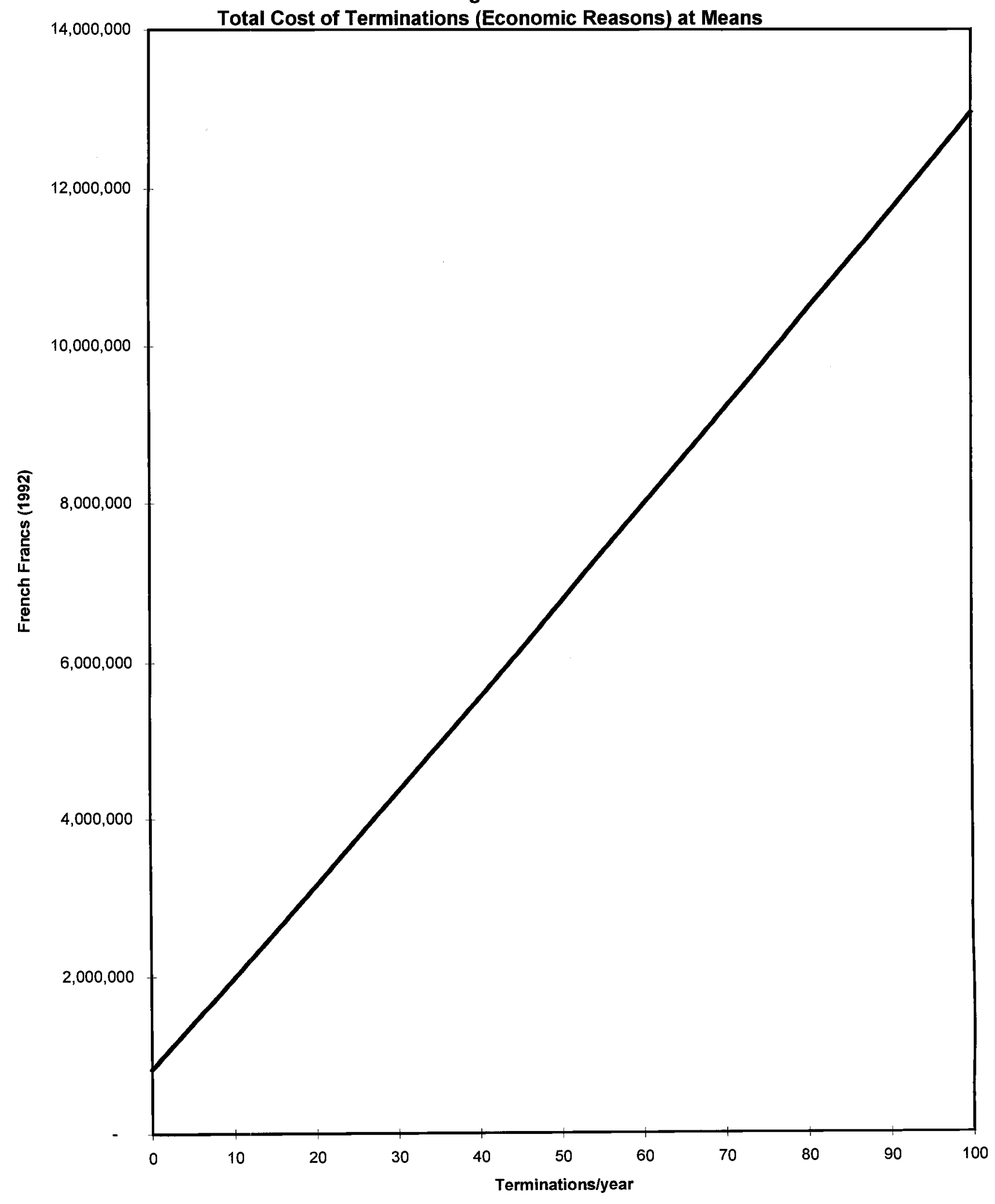

